\title{
PATTERNS AND CONTROLS ON THE DISTRIBUTION OF DIAMOND PIPES IN AUSTRALIA
}

\author{
A.L. Jaques and P.R. Milligan \\ Geoscience Australia, Canberra, Australia
}

\section{INTRODUCTION}

Kimberlites and other alkaline ultrabasic rocks are restricted to particular provinces and fields that commonly exhibit regional and local structural control, notably regional fractures and faults. Intraplate continental alkaline rocks commonly have a relationship with rifting but a range of geotectonic models have been proposed for kimberlites.

We have used GIS and 3D interactive visualisation to examine the distribution of kimberlite, lamproite and related intrusions in Australia in relation to Geoscience Australia's continent-scale geological and geophysical datasets, including magnetic, gravity, seismic, heat flow, and digital elevation model (DEM). Our objective is the development of improved targeting criteria for area selection in diamond exploration by better constraining the relationship between lithospheric especially crustal - thickness and structures and the locations of diamond pipes, enabling better definition of prospective domains and corridors.

There are more than 450 occurrences of kimberlite, lamproite and lamprophyre known in Australia, most found in the course of diamond exploration over the past 25 years. They range in age from $\sim 2050 \mathrm{Ma}$ to 20 Ma and occur in or at the margin of all the major Precambrian provinces of Australia. In addition, a significant number of alkali basalt breccia pipes and lamprophyre dykes occur within the Tasman Orogenic System of Eastern Australia. A 1:5 million scale map showing the distribution of Australian kimberlites, lamproites and related rocks is available free on-line from the Geoscience Australia website (Jaques, 2002). Approximately $25 \%$ of the known intrusions are diamondiferous but less than $10 \%$ have grades $>5 \mathrm{c} / 100 \mathrm{t}$. Economic deposits are associated with lamproite intrusions at 1200 (Argyle) and $20 \mathrm{Ma}$ (Ellendale), and kimberlite intrusions at $360 \mathrm{Ma}$ (Merlin). The distribution of diamondiferous intrusions is shown in Figure 1.

\section{LITHOSPHERIC ROOTS}

Globally, diamondiferous kimberlites are typically restricted to ancient cratons underlain by well-preserved lithospheric roots (e.g., Helmstaedt and Gurney, 1995). Kimberlites occur both within and on the margins of the major Australian Precambrian cratons (Yilgarn, Pilbara, Gawler cratons) and within the large north Australia crustal mega-element of Shaw et al. (1995) that includes the Kimberley Craton. Lamproite intrusions are restricted to the Halls Creek and King Leopold Orogens and the Fitzroy Trough at the SE and SW margins respectively of the Kimberley Craton. Lamprophyres occur within but particularly at the margins of cratons (see Jaques, 2002).

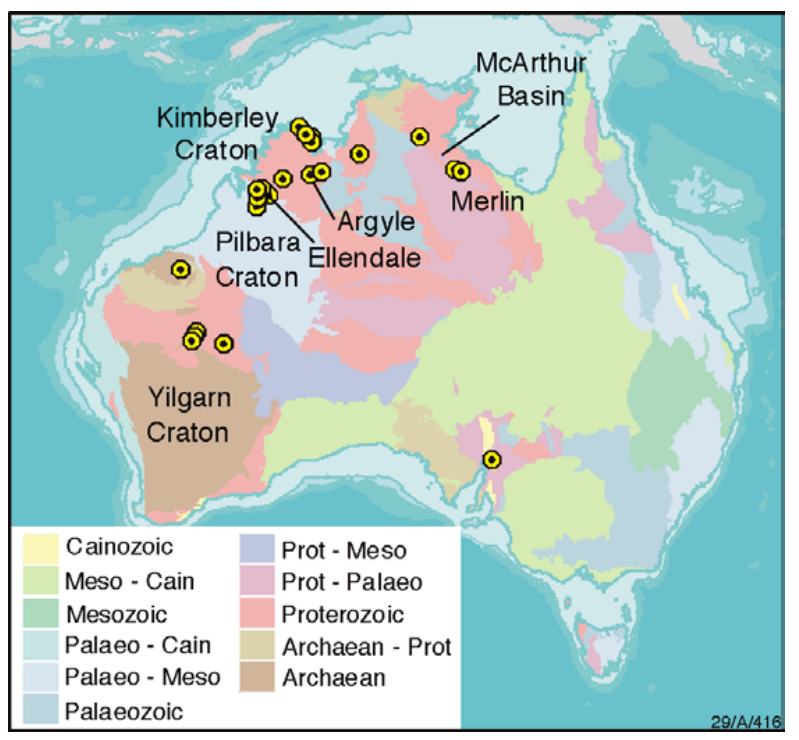

Figure 1. Distribution of diamondiferous kimberlites, lamproites and ultramafic lamprophyres in relation to the major geological provinces of Australia.

Seismic tomographic data obtained in the SKIPPY experiment (and subsequently) show that the Precambrian cratons of Australia are underlain by anomalous high-velocity material that extends to 200 $\mathrm{km}$ and locally to $300 \mathrm{~km}$, suggesting an average lithospheric thickness of around $200 \mathrm{~km}$ (van der Hilst et al., 1998; B. Kennett, pers.comm. 2003). The present lateral resolution of the Skippy data $(\sim 250-500 \mathrm{~km})$ is not adequate to precisely define prospective lithospheric domains. However, the seismic tomographic model suggests that the diamondiferous kimberlites and lamproites of northern Australia lie within regions underlain by lithosphere $\geq 150 \mathrm{~km}$ thick: these lithospheric keels potentially lie in the diamond 
stability field. The tomographic data also indicate that the lithosphere under much of Proterozoic northern Australia is $>200 \mathrm{~km}$ and locally $>250 \mathrm{~km}$ thick. Lithosphere beneath the Kimberley Craton, host to the largest number of diamondiferous bodies, is thinner $(<200 \mathrm{~km}$, thicker in the SE under the Halls Creek Orogen) than, and apparently distinct from, that beneath other parts of northern Australia (van der Hilst et al., 1998). Petrologic studies of peridotite xenoliths and inclusions in diamonds from Argyle and Ellendale (Jaques et al., 1990), and heavy mineral concentrate from kimberlites (O'Reilly et al., 1997) indicate depleted lithospheric mantle at depths of $\sim 150 \mathrm{~km}$ in nthe west (Ellendale), $\sim 160 \mathrm{~km}$ in the north, and $\sim 180$ $\mathrm{km}$ in the east (Argyle).

Simons et al. (1999) found a broad relationship between lithospheric wave speed and increasing crustal age but noted significant variations in deep continental structure within regions of similar crustal age and tectonic setting. Similarly, the patterns of crustal thickness do not match the crustal mega-elements (Collins et al., 2003). Most diamondiferous occurrences lie within regions with relatively thick crust (typically $35-45 \mathrm{~km}$ ) and low present-day heat flow values.

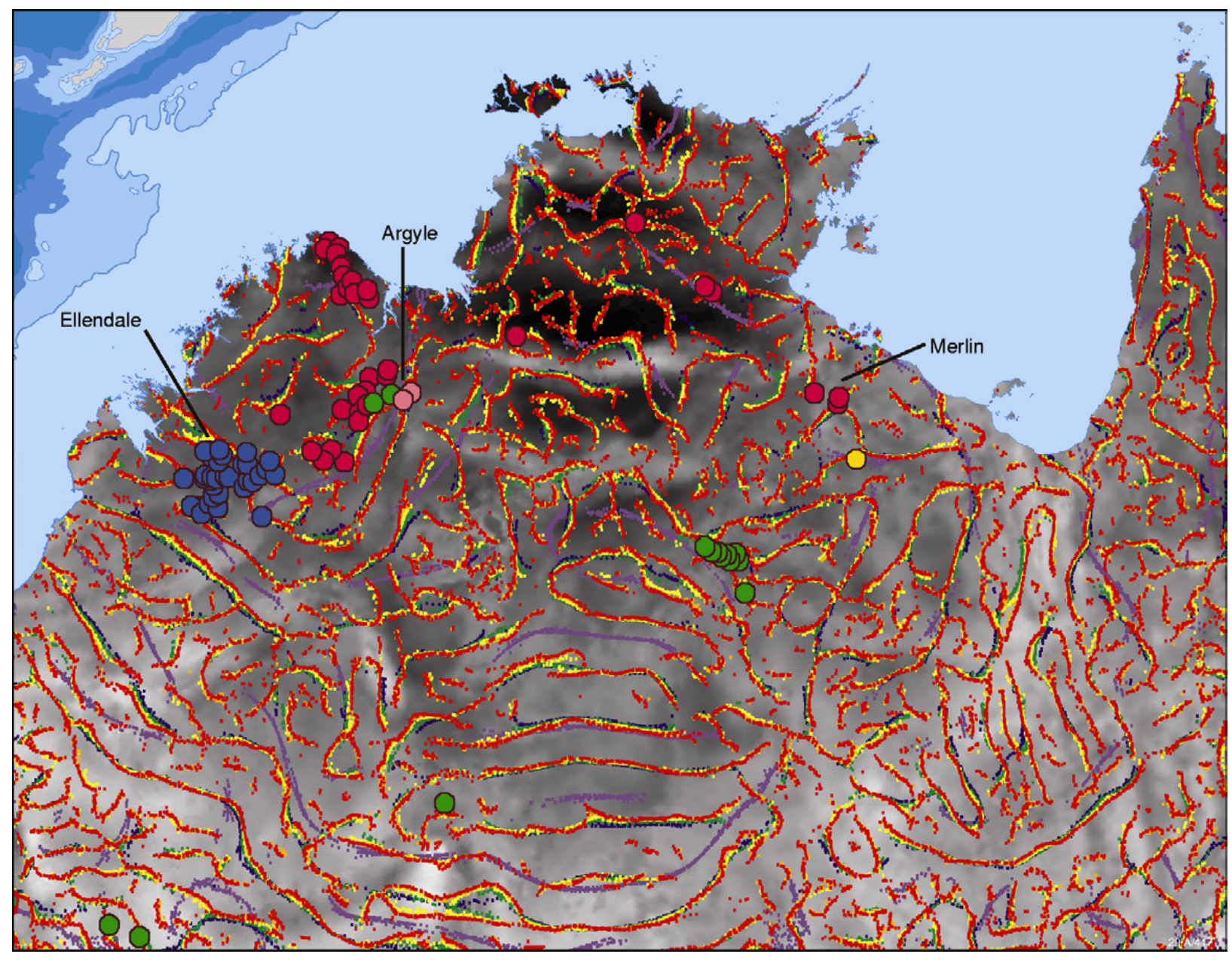

Figure 2. Image map of north Australia showing the distribution of kimberlites, lamproites and lamprophyres in relation to total horizontal gradients in gravity data upward continued from 16,000 m (red) to 100,800 m (blue). The horizontal gradients define domains and structures within the Bouguer gravity anomaly data (greyscale). The upward continuations successively filter out shorter wavelengths (shallower features) in the data, revealing more of the longer wavelength (deeper) features. Locations of intrusions shown as coloured dots: kimberlites (pink), 1200 Ma lamproites (pale pink), 20 Ma lamproites (blue), lamprophyres (green) and Coanjula alkaline intrusions (yellow). 
Crust under the Kimberley Craton is $\sim 35 \mathrm{~km}$ thick but thickens toward the SE to $\sim 40 \mathrm{~km}$ under the Argyle pipe. The thickest crust lies in the SE of the north Australia crustal mega-element where it reaches $\sim 45 \mathrm{~km}$ under the Merlin pipes and $>50 \mathrm{~km}$ under the Mt Isa region.

\section{STRUCTURAL CONTROLS}

A number of kimberlite and lamproite fields, and individual intrusions within them, align along known faults and other structures suggesting that crustal structures influenced emplacement (e.g., Jaques et al., 1986; White et al., 1995).

Potential field data, especially the total horizontal gradients of upward continued gravity data (Figure 2), show discontinuities and structures within the larger crustal elements defined by Shaw et al. (1995) on the basis of continental-scale gravity and magnetic data (Archibald et al., 1999; Milligan et al., 2003). These are interpreted to represent large-scale structures deep in the crust. Many of the kimberlite, lamproite and lamprophyre occurrences appear to be associated with these discontinuities. Many of these structures are not shown on published geological maps and some are discordant to mapped faults suggesting that the gravity discontinuities may reflect more fundamental changes in gravity deeper in the crust.

Figure 2 shows that, at the craton scale, several of the kimberlite, lamproite and lamprophyre fields lie on prominent discontinuities in the horizontal gradients of gravity data upward continued from 16 to $100 \mathrm{~km}$ and reduced-to-pole (RTP) magnetic data. This is particularly evident in the Kimberley Craton. For example, the world-class Argyle lamproite pipe, together with nearby diamondiferous Lissadell Road and Seagull dykes and the non-diamondiferous Bow Hill ultramafic lamprophyre, lies at a break in a prominent NE-trending discontinuity associated with a major gravity high in the Halls Creek Orogen at the SE margin of the Kimberley Craton. The intrusions lie at the northern end of the gravity high that marks the boundary between two of the geophysical domains identified in the Halls Creek Orogen by Shaw et al. (1995, 2000). The Halls Creek Orogen itself coincides with an abrupt change in upper mantle structure at $200 \mathrm{~km}$ (van der Hilst et al., 1997) and may represent a former (Palaeoproterozoic) plate boundary. Immediately west of Halls Creek Orogen other intrusions in the East Kimberley - such as the Maude Creek, Blackfellow Creek and Devils Elbow kimberlite dykes - are strongly aligned along NE-trending structures evident in both the upwardly continued gravity and magnetic data. Further west in the Phillips Range the Aries kimberlite lies near a prominent NNEtrending discontinuity in the upwardly continued gravity data (Figure 2).

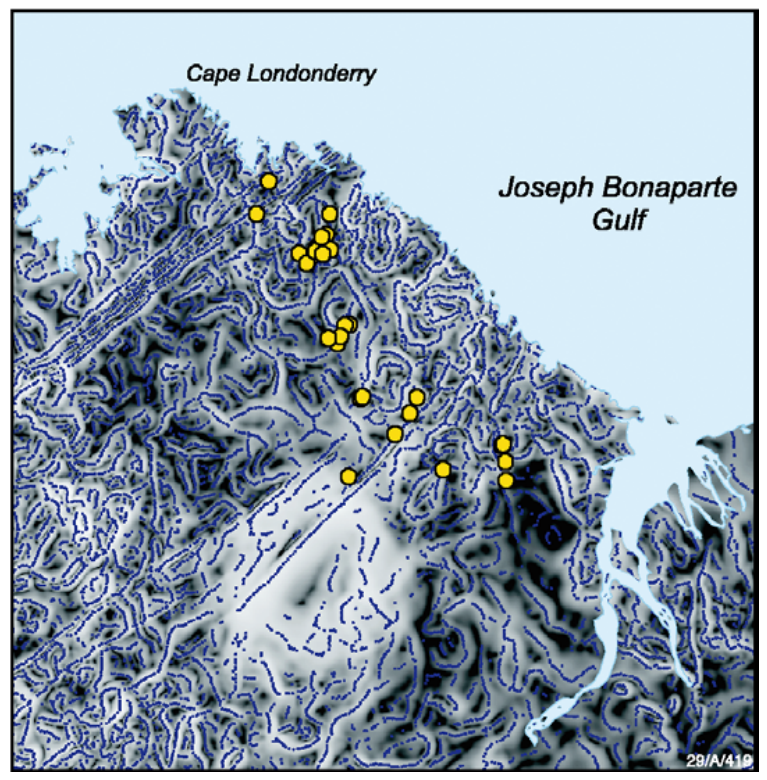

Figure 3. Image map of North Kimberley region showing distribution of kimberlites in relation to the total horizontal derivative (upward continued to $1600 \mathrm{~m}$ ) of total magnetic intensity (RTP) as a greyscale image overlain with points calculated at the maxima of the horizontal gradients.

At the northern margin of the Kimberley Craton the 800 Ma kimberlites of the North Kimberley province are clustered along a broad NW-trending gravity high that is aligned roughly parallel to the coast in the Joseph Bonaparte Gulf (Figure 2). Locally, however, emplacement appears to have been influenced by dominant NE and less prominent NW- and N-trending structures evident in RTP magnetic images (Gun and Meixner, 1998) and in upwardly continued magnetic data (Figure 3). For example, the Ashmore-BulgurriDioro, Seppelt, and Berkeley kimberlite clusters all show a strong NE alignment that, with the apparent exception of the Seppelt pipes, coincides with NEtrending discontinuities identified in the gravity data upwardly continued to $\sim 60 \mathrm{~km}$. The Delancourt kimberlites, however, are aligned on a NNW-trending discontinuity evident in the DEM and magnetic data (Figure 3) that is not evident in the gravity. Both the gravity and especially the magnetic data show the marked conjugate NW-NE and subordinate N-trending 
discontinuities of the Kimberley Craton. The conjugate NW-NE series of magnetic anomalies in the North Kimberley have been interpreted as having formed by differential basement extension during DevonianCarboniferous rifting in the central Joseph Bonaparte Gulf (Gunn and Meixner, 1998). The apparent spatial association of these structures with the $800 \mathrm{Ma}$ kimberlites suggests that at least some of the structures, especially those defined in the gravity data, may be older, perhaps formed associated with the breakup of Rhodinia and may have been reactivated during the later extension.

The distribution of lamproites in the West Kimberley, especially in the Ellendale field, appears to be influenced by basement structures at the northern margin of the Fitzroy Trough evident in the magnetic and upwardly-continued RTP magnetic data. In addition to the dominant NW-trending (highs) and subordinate E-trending (lows) gradients, the upwardly continued magnetic data show ENE and E-trending discontinuities with which a number of pipes (e.g. 81 Mile Vent, Mt Percy, Ellendale 2, 6) are associated. Recent more detailed proprietary aeromagnetic surveys confirm the existence of prominent E-trending structures that appear to have controlled the emplacement of many of the Ellendale lamproite intrusions, as shown by the E-W locus and elongation of volcanic vents. White et al. (1995) related the distribution of lamproites in the West Kimberley to the major mantle-penetrating shear system that forms the contact between the King Leopold Orogen and the Lennard Shelf at the northern margin of the Fitzroy Trough. This Proterozoic compressional structure was reactivated as a detachment zone during late Palaeozoic basin extension (Braun and Shaw, 1998).

Similarly, the Mesozoic (inferred age) Roper and Stow kimberlites in the McArthur Basin region coincide with a broad NW-trending discontinuity evident in gravity datasets upwardly continued to $\geq 100 \mathrm{~km}$ that extends from the Mount Isa to the Pine Creek Inliers (the 'Barramundi worm' of Hobbs et al., 2000). At lower levels of upward continuation shallower features predominate, and the major broad discontinuity is much less evident and replaced by a meshwork of relatively small NW, NE, and E-trending discontinuities (Figure 4).

The Merlin kimberlites lie along a prominent NEtrending gravity discontinuity (Figure 2) but locally lie immediately north of the NNW-trending Emu Fault at the intersection of the NE-trending gravity discontinuity, a subordinate N-trending gravity discontinuity, and an inferred extension of the NWtrending Calvert Fault. The Roper and Abner Range kimberlites, and the Coanjula alkaline intrusions appear to lie at or close to discontinuities in the Bouguer gravity (Figure 4).

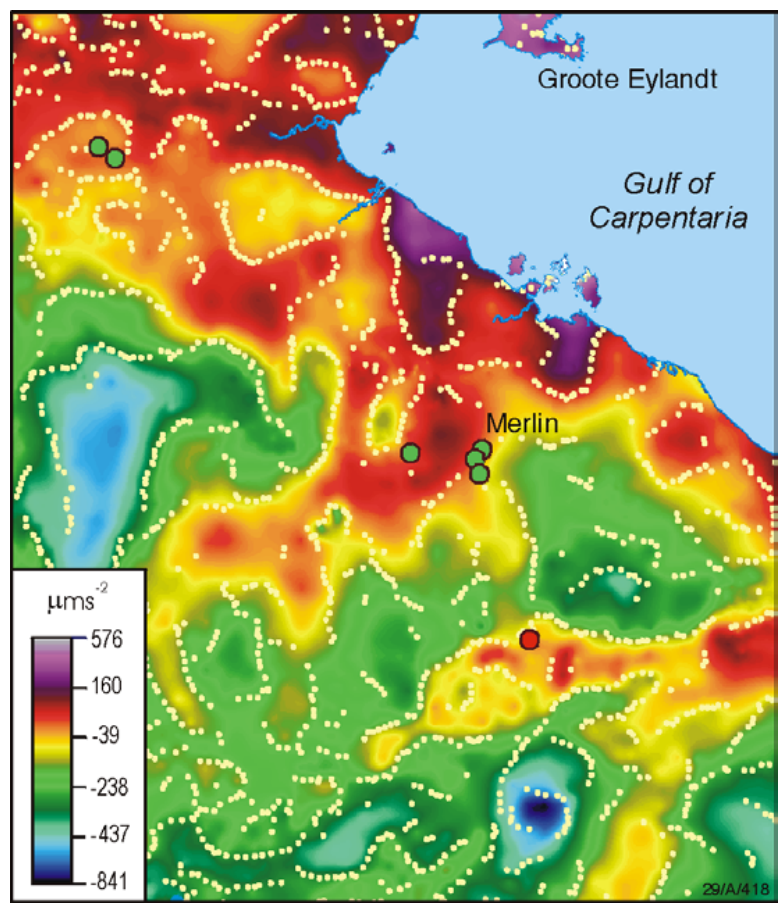

Figure 4. Image map of the McArthur Basin, NT showing the distribution of Merlin (M), Abner Range and Roper field kimberlites (green dots) and Coanjula alkaline intrusions (red dot) in relation to ground level gravity in colour (magenta high, blue low) overlain with points calculated at the maxima of the horizontal gradient for an upward continued level of $5600 \mathrm{~m}$.

\section{CONCLUSIONS}

This analysis suggests that kimberlite, lamproite and lamprophyre intrusions are commonly closely associated with crustal structures that can be identified in potential field data, even at the continental scale. Many of these structures, however, are either not evident or only weakly visible in primary magnetic and gravity datasets where they are masked by shorter wavelengths (near surface anomalies); they are revealed as discontinuities in the total horizontal gradients of the upward continued data. The origin of these features is an area of ongoing investigation: we suggest that some of the density discontinuities evident in gravity data upward continued for many tens to hundreds of kilometres may mark different lithospheric blocks. Analysis of horizontal and other gradients in upwardly- 
continued potential field data at all scales assists definition of crustal and potentially lithospheric structures and hence is a potentially useful additional tool in defining prospective domains and corridors in diamond exploration.

\section{ACKNOWLEDGEMENTS}

The authors thank Rex Bates for assistance with the figures and Barry Drummond, Clive Collins and Dean Hoatson (all al Geoscience Australia) for comments on the manuscript. Publication is with permission of the Chief Executive Officer, Geoscience Australia.

\section{REFERENCES}

Archibald, N., Gow, P., Boschetti, F., 1999. Multiscale edge analysis of potential field data. Exploration Geophysics 30, 38-44.

Braun, J., Shaw, R.D., 1998. Extension in the Fitzroy Trough, Western Australia: an example of reactivation tectonics. In: Braun., J et al. (Eds), Structure and evolution of the Australian continent. AGU Geophysical Series, AGU, Washington, DC, pp.157174.

Collins, C.D.N., Drummond, B.J., Nicoll, M.G., 2003. Crustal thickness patterns in the Australian continent. Geological Society of Australia, Special Publication 22, 115-122.

Gunn, P.J., Meixner, A.J. 1998. The nature of the basement to the Kimberley Block, Northwestern Australia. Exploration Geophysics 29, 506-511.

Helmstaedt, H., Gurney, J.J., 1995. Geotectonic controls primary diamond deposits: Implications for area selection. Journal of Geochemical Exploration 53, 125-144.

Hobbs, B.F, Ord, A., Archibald, N.J., Walshe, J.L., Zhang, Y., Brown, M., Zhao, C., 2000. Geodynamic modeling as an exploration tool. In: After 2000: the future of mining. AusIMM Publication, Series 2/2000.

Jaques, A.L., 2002. Australian diamond deposits, kimberlites, and related rocks. 1:5 million map, Geoscience Australia. www.ga.gov.au/pdf/RR0114.pdf

Jaques, A.L., O’Neill, H.St.C., Smith, C.B., Moon, J., 1990. Diamond-bearing peridotite xenoliths from the Argyle (AK1) pipe. Contributions to Mineralogy and Petrology 255-276.

Jaques, A.L., Lewis, J.D., Smith, C.B., 1986. The Kimberlites and Lamproites of Western Australia. Geological Survey of WA, Bulletin 132.

Milligan, P.R., Lyons, P. Direen N.G., 2003. Spatial and directional analysis of potential field gradients - new methods to help solve and display three-dimensional crustal architecture. ASEG $16^{\text {th }}$ Geophysical
Conference and Exhibition, Adelaide. Extended Abstracts.

O’Reilly, S.Y., Griffin, W.L., Gaul, O., 1997. Paleogeothermal gradients in Australia: key to 4-D lithosphere mapping. AGSO Journal of Australian Geology \& Geophysics. 17, 63-72.

Shaw, R.D., Wellman, P., Gunn, P., Whitaker, A.J., Tarlowski, C., Morse, M., 1995. Australian crustal element map: a geophysical model for the tectonic framework of the continent. AGSO Research. Newsletter. 23, 1-3.

Shaw, R.D., Meixner, T.J., Murray, A.S., 2000. Regional geophysical setting and tectonic implications of the mafic-ultramafic intrusions. In: Hoatson, D.M., Blake, D.H. (Eds), Geology and economic potential of the Palaeoproterozoic layered mafic-ultramafic intrusions in the East Kimberley, Western Australia. AGSO Bulletin 246.

Simons, F.J., Zielhuis, A., van der Hilst, R.D., 1999. The deep structure of the Australian continent from surface wave tomography. Lithos 48, 17-43.

Van der Hilst, R.D., Kennett, B.L.N., Shibatani, T., 1998. Upper mantle structure beneath Australia from portable array deployment. In: Braun., J et al. (Eds), Structure and evolution of the Australian continent. AGU Geophysical Series, AGU, Washington, DC, pp.39-57.

White, S.H., de Boorder, H., Smith, C.B., 1995. Structural controls of kimberlite and lamproite emplacement. Journal of Geochemical Exploration 53, 245-264.

Contact: A.L. Jaques, Geoscience Australia, GPO Box 378, Canberra, ACT, 2615, Australia, E-mail: lynton.jaques@ga.gov.au 